\title{
CONCENTRATION OF MINERAL SUBSTANCES IN THE TIBIOTARSUS OF THE JAPANESE QUAIL IN WEIGHTLESSNESS
}

\author{
K. BODA ${ }^{1}, \mathrm{~J}$. ILLEK ${ }^{2}$, V. SABO 3 \\ ${ }^{1}$ Institute of Experimental Veterinary Medicine, 90028 Ivanka pri Dunaji \\ Slovak Republic \\ 2 Veterinary and Pharmaceutical University, Palackého 1-3, 61242 Brno, Czech Republic \\ ${ }^{3}$ Institute of Biochemistry and Genetics, Slovak Academy of Sciences, Ivanka pri Dunaji, Slovak Republic \\ Received December 7, 1995 \\ Accepted June 6, 1996
}

\begin{abstract}
B od a K., J. I1l e k, V.S a b o: Concentrations of Mineral Substances in the Tibiotarsus of the Japanese Quail in Weightlessness. Acta vet. Brno 1996, 65: 33-37.

The concentrations of $\mathrm{Ca}, \mathrm{P}, \mathrm{Mg}$, and $\mathrm{Na}$ were studied in the tibiotarsus of 17-day-old embryos of Japanese quail, in quail 2-4 days of post-embryonic development in the MIR orbital station, and in adult birds of both sexes exposed to 7 days of weightlessness. In addition, $\mathrm{Ca}, \mathrm{P}, \mathrm{Mg}$ levels were determined in shells of eggs from which the quail hatched during the orbital flight.

Differences between Ca and P levels were found in quail of different sex. In the male bird, the $\mathrm{Ca}$ concentration decreased during the flight. In the female quail this did not happen due to interrupted ovulation. These results are probably associated with the intensity of reabsorption of the elements from the bone tissue in dependence on egg formation. In the control experiment, the level of $\mathrm{Mg}$ in female quail was found to be lower. It is probably also associated with $\mathrm{Mg}$ reabsorption from the bones, necessary for the regulation of the intensity processes of egg calcification in the uterus.
\end{abstract}

Bone, egg shell, $\mathrm{Ca}, \mathrm{Mg}, \mathrm{P}$, Na concentrations

In weightlessness, demineralization takes place in weight-loaded human bones. This process is dependent on the length of the cosmic flight, the longer the flight the stronger it is (V o g e 1 et al. 1974). Osteoporosis also develops in weight-loaded bones of 19-22 dayold rats (J a g o d o v s ki et al. 1976).

After 5 days in weightlessness, the concentration of $\mathrm{Ca}$ in the proximal epiphysis of the humerus of pregnant rats decreased. The $\mathrm{P}$ concentration in bone tissue increased, leading to a lower $\mathrm{Ca}: \mathrm{P}$ ratio (O $\mathrm{g}$ a n o $\mathrm{v}$ et al. 1988). Another study revealed that a 14-day period of weightlessness caused a re-distribution of $\mathrm{Ca}, \mathrm{P}, \mathrm{Mg}$ and $\mathrm{Zn}$ in the bones of the skeleton. The reduction of macroelements was the strongest in the metaepiphyseal part of the tibia (B u rk o v s k a y a et al. 1991).

During chick embryogenesis that took place in the SHUTTLE-Discovery flight experiment (STS-29), the levels of $\mathrm{Ca}, \mathrm{P}$ and $\mathrm{Mg}$ were studied in egg shells of embryos exposed to 6 days of weightlessness, i. e. between days 2 and 7, and between days 9 and 14 of incubation (H e s t e r et al. 1993). No significant changes were found in concentrations of the studied macroelements. However, no data are available on the concentrations of minerals in egg shells after a complete embryogenesis in weightlessness.

In this short paper we present the data on mineral substances in the tibiotarsus of quail embryos, at the beginning of their postembryonic life, further in both male and female adult quail, and in the egg shells, all obtained in the conditions of space flight.

\section{Materials and Methods}

The material was obtained from the experiment Incubator 2A and Incubator 2B of the MIR orbital station (B od a et al. 1992). The first experiment (Incubator 2A) was carried out between the 4th and 21st March 1990, the second (Incubator 2B) between the 1st and 9th August 1990. Embryogenesis and the 2-4 days of postembryonal development of the Japanese quail was studied in the first experiment, and the sensory-motor and feeding behaviour of adult quail in the second. 
In the present study, the content of $\mathrm{Ca}, \mathrm{P}, \mathrm{Mg}$ and $\mathrm{Na}$ was determined in the tibiotarsus of a 17-day-old embryo, in hatched quail on days $2-4$, and in adult birds after 7 days of exposure to weightlessness. The content of Ca, $\mathrm{P}$ and $\mathrm{Mg}$ were also studied in shells of eggs from which the quail hatched in the Incubator $1 \mathrm{M}$ on the orbital station.

On the orbital station, the 17-day-old embryos and hatched quail aged 2-4 days were fixed in $96 \%$ alcohol, and after landing on Earth they were used for morphological studies of tissues and for analyses of the concentrations of mineral substances in the tibiotarsus.After landing on Earth, 2 female and one male adult quail (out of the 3 females and one male) were killed by decapitation. The leg bones were then prepared and the level of mineral substances was determined in the tibiotarsus. Samples of the bone tissue and egg shells were dried at $105^{\circ} \mathrm{C}$, mineralized using the dry way at $540-560^{\circ} \mathrm{C}$ for $48 \mathrm{~h}$. The ash was dissolved in a mininum amount of $\mathrm{HNO}_{3}$ and deionized water was added to constant volume. In this solution, concentrations of $\mathrm{Ca}, \mathrm{Mg}$ and $\mathrm{Na}$ were determined using the method of atomic absorption spectrophotometry (AAS) and the apparatus ATOMSPEK H1551. The concentration of P was determined photometrically by a Bio-La-test (Lachema, Brno, Czech Republic). The concentration of mineral substances was expressed per $1 \mathrm{mg} \cdot \mathrm{g}^{-1}$ of bone tissue ash, and their concentration in the egg shell per mg. $\mathrm{g}^{-1}$ shell dry matter. Due to the limited number of experimental birds, only the bones of one bird from the experimental flight and of one control bird were analyzed. For analyses of the egg shells, a joint sample was used consisting of 6 eggs from the experimental flight, and from the control and synchronous experiment.

\section{Results and Discussion}

The results of this experiment can serve as a pilot study only. However, since the material is unique, they are an extremely valuable source of information. These are the first results obtained from embryos of the Japanese quail during postembryonic development and from adult birds of both sexes kept in weightlessness. Tab.1 gives the values of $\mathrm{Ca}, \mathrm{P}, \mathrm{Mg}$ and $\mathrm{Na}$ in the tibiotarsus of 17-day-old embryos of the Japanese quail.

Table 1

The concentrations of $\mathrm{Ca}, \mathrm{P}, \mathrm{Mg}$ and $\mathrm{Na}$ in the tibiotarsus of 17-day-old Japanese quail embryos (mg.g-1)

\begin{tabular}{|lccccc|}
\hline & $\mathrm{Ca}$ & $\mathrm{P}$ & $\mathrm{Mg}$ & $\mathrm{Na}$ & $\mathrm{Ca}: \mathrm{P}$ \\
\hline flight experiment & 335.3 & 176.4 & 12.7 & 23.3 & 1.9 \\
control & 419.6 & 209.7 & 14.6 & 30.4 & 2.0 \\
\hline
\end{tabular}

Table 2

The concentrations of $\mathrm{Ca}, \mathrm{P}, \mathrm{Mg}$ and $\mathrm{Na}$ in the tibiotarsus of Japanese quail aged 2-4 days (mg.g ${ }^{-1}$ )

\begin{tabular}{|lccccc|}
\hline & $\mathrm{Ca}$ & $\mathrm{P}$ & $\mathrm{Mg}$ & $\mathrm{Na}$ & $\mathrm{Ca}: \mathrm{P}$ \\
\hline flight experiment & 410.0 & 207.1 & 15.3 & 21.6 & 1.98 \\
control & 385.8 & 183.7 & 16.2 & 48.9 & 2.1 \\
\hline
\end{tabular}

Tab. 2 gives the values of the mineral substances in 2-4-day old Japanese quail.

The results do not indicate any changes in the concentration of the studied elements during the flight experiment and in the controls, and no substantial differences among the values obtained from 17-day-old embryos and 2-4-day old Japanese quail. No changes seem to occur in Japanese quail during embryogenesis and in days 2- 4 after hatching in terms of the concentrations of the studied mineral substances due to weightlessness. Furthermore, as can be seen in Tab. 3, no quantitative differences in the levels of $\mathrm{Ca}, \mathrm{P}$ and $\mathrm{Mg}$ in the egg shells were found between the experimental flight and the controls. H e s $t$ e $r$ et al. (1994) obtained similar results in shells of hens' eggs in weightlessness, even though under different experimental conditions.

Table 3

The levels of $\mathrm{Ca}, \mathrm{P}$ and $\mathrm{Mg}$ in shells of eggs of Japanese quail after incubation and hatching in weightlessness $\left(\mathrm{mg}^{-1} \mathrm{~g}^{-1}\right)$

\begin{tabular}{|llll|}
\hline & Ca & P & Mg \\
\hline flight experiment & 329.2 & 1.34 & 4.12 \\
synchronous control & 328.8 & 1.22 & 3.92 \\
control & 330.9 & 1.26 & 3.80 \\
\hline
\end{tabular}


Table 4

The levels of $\mathrm{Ca}, \mathrm{P}, \mathrm{Mg}$ and $\mathrm{Na}$ in the tibiotarsus of male quail after a 7-day exposure to weightlessness (mg.g-1)

\begin{tabular}{|lccccc|}
\hline & $\mathrm{Ca}$ & $\mathrm{P}$ & $\mathrm{Mg}$ & $\mathrm{Na}$ & $\mathrm{Ca}: \mathrm{P}$ \\
\hline flight experiment & 272.0 & 137.4 & 59.5 & 39.1 & 1.98 \\
control & 411.9 & 204.4 & 51.4 & 50.7 & 2.01 \\
\hline
\end{tabular}

Table 5

The levels of $\mathrm{Ca}, \mathrm{P}, \mathrm{Mg}$ and $\mathrm{Na}$ in the tibiotarsus of female quail after a 7-day exposure to weightlessness (mg.g-1)

\begin{tabular}{|lccccc|}
\hline & $\mathrm{Ca}$ & $\mathrm{P}$ & $\mathrm{Mg}$ & $\mathrm{Na}$ & $\mathrm{Ca}: \mathrm{P}$ \\
\hline flight experiment & 331.4 & 171.7 & 43.4 & 79.5 & 1.93 \\
control & 329.8 & 164.9 & 27.8 & 86.1 & 2.00 \\
\hline
\end{tabular}

Tab.4 gives the results obtained from male Japanese quail and Tab.5 gives the results for female quail.

The results show the evident differences in $\mathrm{Ca}$ and $\mathrm{P}$ concentrations between the males and females. In the male quail the measured values were considerably lower in the flight experiment as compared with the control, while the same values in the female were balanced. In the male birds, the resorption of $\mathrm{Ca}$ and $\mathrm{P}$ from the bones apparently increased due to the 7 days of weightlessness, while in the female quail this phenomenon could have affected the values found in the controls where the bird was going through ovulation and formation of egg, including the egg shell. Ovulation did not occur in the female Japanese quail during the flight experiment due to hypertrophy of the ovaries (B o d a et al. 1991). The resorption of $\mathrm{Ca}$ and $\mathrm{P}$ from the bones, due to ovulation and egg formation was probably higher in control quail than it was in weightlessness with no ovulation and egg formation. The lower values of $\mathrm{Mg}$ in the female control quail might also bear evidence of a higher resorption of $\mathrm{Mg}$ from the bones, because a higher level of $\mathrm{Mg}$, as a factor regulating the intensity of the process of calcification of the eggs, is necessary in the uterus (Georgijevskij et al. 1979).

The first preliminary information about the level of macroelements in the tibiotarsus of the Japanese quail indicated that 7 days of weightlessness influenced the increased resorption of $\mathrm{Ca}, \mathrm{P}$ and $\mathrm{Mg}$. Further studies of the metabolism of mineral substances and of the possibilities of influencing it in productive birds under conditions of lower gravity showed that under these conditions metabolism has a limiting efffect on egg production, particularly on egg shells. This is based on the specific character of metabolism, especially of $\mathrm{Ca}$, in birds. During the stage of reproduction, Ca metabolism is 20 times quicker than in mammals. Embryonic development of birds outside the organism is possible only due to a balanced level of nutrients, including mineral substances, in the egg. More than $80 \%$ of $\mathrm{Ca}$ is transferred to the embryo from the shell.

The skeleton of birds, particularly of layers, not only has the function of homeostasis, natural for all vertebrates, but it immediately participates in egg formation. This function of the skeleton is sometimes so intensive that it is to the detriment of the firmness of the bones.

Further studies of the metabolism of mineral substances in commercial birds are very important also in terms of comparative aspects of gravitational physiology. It links up with comparative studies of osteodystrophic processes in animals on different levels of phylogenesis. The effect of factors of cosmic flights on these processes was studied in tortoises and rats. After 60 to 90 days of being exposed to weightlessness, the tortoises developed a not very strong osteoporosis in the epiphyses and metaphyses of the long bones without changes in the degree of mineralization of the preserved microstructures. The same 
changes were observed in rats, with the only difference that after 90 days of the flight experiment, rats lost $20 \%$ of their spongy bone tissue, and the tortoises lost $4-8 \%$ after 60 90 days (Grig orye $v$ et al. 1994). This is a proof of the different intensity of metabolic processes of phylogenetically different organisms, and it must be taken into account when investigating the general interspecific regularities of dystrophic changes in bones under conditions of weightlessness.

In this area, commercial birds are interesting, they have a high intensity of metabolism of mineral substances. The importance of further investigations is dictated not only by practical needs of functional incorporation of the commercial hypertrophic organism into a closed cosmic ecosystem, but also by interest in enrichment gravitational physiology with new information.

\section{Obsah minerálnych látok $\mathrm{v}$ tibiotarze japonských prepelíc $\mathrm{v}$ beztiažovom stave}

$\mathrm{V}$ pokuse bol sledovaný obsah $\mathrm{Ca}, \mathrm{P}, \mathrm{Mg}$ a Na v tibiotarze 17-dňových embryí japonskej prepolice, 2-4 dni starých jedincov a dospelých jedincov (samcov i samíc) na orbitálnej stanici Mir, exponovaných 7 dní beztiažovému stavu. Koncentrácia $\mathrm{Ca}, \mathrm{P}, \mathrm{Mg}$, bola stanovená aj v škrupinách vajec, $\mathrm{z}$ ktorých sa na orbite prepelice vyliahli.

$\mathrm{V}$ hodnotách $\mathrm{Ca}$ a $\mathrm{P}$ boli rozdiely medzi pohlaviami. Koncentrácia $\mathrm{Ca}$ bola $\mathrm{u}$ jediného samca v letovom pokuse znížená. U samičiek sa táto tendencia neprejavila vzhladom na preruŠenie ovulácie. Tieto výsledky pravdepodobne súvisia s intenzitou resorpcie týchto prvkov z kostného tkaniva v závislosti na tvorbe vajca. Zistila sa nižšia koncentrácia Mg u samičky v kontrolnom pokuse, čo je tiež zrejme spojené $s$ procesom rezorpcie $\mathrm{Mg} \mathrm{z}$ kostí, ktorý je potrebný $v$ maternici pre reguláciu intenzity procesov kalcifikácie.

\section{Содержание минеральных веществ в тибиотарзии японских перепелок В состоянии невесомости}

Проводили исследования содержания $\mathrm{Ca}, \mathrm{P}, \mathrm{Mg}, \mathrm{Na}$ в тибиотарзии 17-суточных зародышей японской перепелки, перепелки в 2-4-суточном попстэмбриональном развитии на космической станции МИР и взрослых перепелок обоих полов, находящихся в течение 7 суток в состоянии невесомости. Уровень Сa, P, Mg определяли также в скорлупе яиц, из которых на орбите вылупились перпелки.

Проводили исследования разницы велиечин Са и $\mathrm{P}$ перепелок разного пола. У особей мужского пола наблюдали пониженный уровень Са в ходе летных испытаний. У перепелок женского пола, учитывая прекращение овуляции, упомянутая тенденция не выявилась. Приведенные результаты вероятно связаны с интенсивностью резорбции данных элементов из костной ткани в зависимости от образования яйца. Был установлен более низкий уровень Mg самок перепелок в контрольном испытании. Это, по всей вероятности, также связано с процессом резорбции Мg из костей, необходимого в матке для регулирования интенсивности процессов кальцификации яиц.

\section{References}

BOḊA, K., SABO, V, JURÁNI, M., GURYEVA, T. S., KOČIŠOVÁ, J., KOŠTÁL, LAUKOVA, A., DADASHEVA, O. A. 1992: Acta vet. Brno 61:99-107

BODAA, K., GURYEVA, T. S., JURÁNI, M., SABO, V., KOŠTÁL, L., DADASHEVA, O. A., KOČIŠOVÁ, J., JANKELA, J., LAUKOVÁ, A., REHÁK, M., ŚNEJDÁRKOVÁ, M. 1991: Current Trends in Cosmic Biology and medicine, Ed. K. Boda and Baranov, Slov. Acad. Sci., pp. 185-201

BURKOVSKAYA, T. E., NAZAROV, V. M., FRONTASJEVA, M. V., GUNDORINA, S. F. 1991: Biosputniki Kosmos, Tezisi dokladov, mežd. sympoziuma, Moskva, pp. 25-26 
GEORGIYEV, A. I., VOLOZHIN, A. I., STUPAKOV, G.P. 1994:Mineralny obmen u cheloveka v usloviyach izmenennoy gravitacii. Moskva, Nauka

HESTER, P. Y., McGINNIS, M. E., VELLINGER, J. C., DEUSER, M.S., FERMIN, C. D. 1993: Acta vet. Brno, Suppl. 6, 62:43-47

JAGODOVSKI, V. S., TRIFTANIDY, L. A., GOROCHOVA, G. P. 1976:Aviat. Space and Environm. Med. 47:734-738

OGANOV, V. S., BAKULIN, A. V., ILJIN, J. A., LEBEDEV, V. I., STUPAKOV, G, P., SHEPPARD, D., ALEXANDRE, C., VICO, L., NOGUES, K., MINER, P. 1988: In Ontogenez mlekopitayushchich zhivotnych v nevesomosti. Moskva, Nauka, pp.60-67

VOGEL, G. M., WHITTLE, M. W. 1974: Proc. Skylab-Life Sci. Symp.1:387-401 